\title{
Theology Before and After Bishop Robinson's Honest to God (1963)
}

\author{
Lloyd Geering \\ lloydgeering0@gmail.com
}

\begin{abstract}
Bishop John Robinson's Honest to God (1963) may be judged as a bombshell that blew the roof off the church, not because it introduced original thinking, but because it brought to unsuspecting people in the pews some knowledge of the developments that had been taking place for quite some time in academic theology. It initiated the turbulent sixties from which time onwards the slow decline in church allegiance began to accelerate in the Western world. The thought of Dietrich Bonhoeffer, Rudolf Bultmann and Paul Tillich, which Robinson summarized in his book, were themselves simply the twentieth century version of the radical changes in theology made necessary by the advent of the post-Enlightenment world, and which had been set in motion in rather different ways at the beginning of the nineteenth century by the philosopher Georg Wilhelm Friedrich Hegel, and the theologian Friedrich Schleiermacher. Since the Enlightenment brought to humans the freedom to think for themselves - Bonhoeffer labelled this phenomenon 'Humanity's coming of age' - so the theological enterprise gradually changed from being the exposition of divinely revealed dogmas to the human exploration of religious experience. In retrospect, Robinson's book is to be judged a significant marker in a process of ever-changing theological thought.
\end{abstract}

Keywords: J.A.T. Robinson, Post-Enlightenment World, humanity's coming of age, theological thought

Fifty-five ago this year Bishop John Robinson published his little book Honest to God. It has been republished in its original form, recently. This book sold 
more quickly and widely than any book of serious theology in the history of the world. I dare to suggest that that record may never be surpassed. Before long its publication had reached a million copies and it was available in 17 languages. Thus no theological book was read so widely as this little volume in the whole of the 20th century. Why was that so?

In some respects it remains a puzzle to this day. It was not because the book was saying anything strikingly new. Those of us engaged in theological teaching at the time found little that was fresh in the book. As we saw it, this book was basically a summarized rehash of the thinking of three theologians whom many of us had been reading and absorbing for some time. We joked that that it had taken an illness to force John Robinson to take time off from his busy ecclesiastical schedule to catch up with his reading.

First, he sketched Paul Tillich. Tillich had written two popular and widely read books - The Shaking of the Foundations and The Courage to Be. The first two volumes of Tillich's massive 3-volume Systematic Theology were published in the 1950's, and Robinson quoted from them. In his search to find a satisfying way of understanding the meaning of 'God' he fastened on Tillich's definition of God as 'the ground of our being'. This showed, as Robinson said, that theology is not about a particular Being called God but about the ultimate questions posed by our very existence or being.

Second, Robinson turned to the impact of Dietrich Bonhoeffer whose letters from a Nazi prison provided a rich collection of seed thoughts that many of us were then mulling over. In particular Robinson was fascinated by Bonhoeffer's new assessment of Jesus as 'the man for others', rather than as a divine figure.

Thirdly, but much less prominent, was the influence of Rudolf Bultmann. His demythologising of the New Testament had become known to scholars outside of Germany only after World War II. Then Robinson added a chapter on 'The New Morality', writing with approval of an article by Joseph Fletcher. But Fletcher's book on Situation Ethics, which was to cause a stir not unlike that of Honest to God, was yet to be written, appearing only in 1966.

Thus Robinson was pulling together the thoughts of a number of theologians who were then at the leading edge of Christian thought. If he had done this in a simpler and more lucid manner than was present in the originals, that would perhaps explain the sudden and widespread interest. But Honest to God is not a particularly easy book for the theologically illiterate to read. Some of us were critical of it at the time just for this reason. To us it seemed a bit of 


\section{Lloyd Geering}

a hotch-potch. Its critics claimed it was woolly and revealed many inconsistencies. Even Robinson himself later said that if he had known it was going to be read so widely he would have written it in a much more accessible style.

So why did it become a runaway bestseller? In small part it was due to a set of chance events surrounding the time of its publication. Not long beforehand, Bishop Robinson had achieved widespread public notoriety over his appearance in a celebrated court case where he publicly defended the publication of the unexpurgated text of Lady Chatterley's Lover. Thus the name of Bishop Robinson was already being bandied about in the public arena and this meant that the journalists were on the alert for anything unusual. So the public press chose to announce the arrival of Robinson's little new book with these words on the billboards - 'Our image of God must go'.

The public impression created from the very beginning was that Robinson was making a break with Christian orthodoxy on the basic issue of the reality of God. Certainly that is made clear on p.13 of the preface where we read, 'Whatever we may accept with the top of our minds, most of us still retain deep down the mental image of 'an old man in the sky'. Certainly, if we keep talking of and praying to, 'Our Father in heaven', how can we avoid having this image of God?

But Robinson was not denying the reality of God but calling for 'a restating of traditional orthodoxy in modern terms' and, for such a recasting, he judged that 'the most fundamental categories of our theology - of God, of the supernatural and of religion itself - must go into the melting'. Yet he was not the first to call for such a radical reconstruction, as we shall presently see. So why the stir?

What was new about this book was that it was written by a bishop. Theologians may question and explore, but bishops are expected to be the authoritative guardians of the faith. Moreover it was written in a personal style in which Robinson confessed his own difficulties with orthodox Christian doctrines. He judged them to be expressed in thought-forms and language that had long become obsolete in the world outside of the church. He guessed that his book would surprise some and so he concluded his short preface with these words

What I have tried to say, in a tentative and exploratory way, may seem to be radical, and doubtless to many heretical. The one thing of which 
I am fairly sure is that, in retrospect it will be seen to have erred in not being nearly radical enough.

Those last words have certainly proved to be all too true.

I conclude that it was the personal and public way in which a bishop (already suspected of being a maverick) openly confessed his own doubts that caused this book to ring bells with hundreds of thousands of church-going people. What came over in the book was Robinson's honesty and frankness about his own theological concerns. Many felt so relieved that a bishop was experiencing the same problems as they did with the traditional formulations of the faith.

By the same token the book brought forth a torrent of criticisms, much more than even Robinson had expected to be the case. The Anglican journal, the Church Times, commented

It is not every day that a bishop goes on public record as apparently denying almost every Christian doctrine of the church in which he holds office.

What we in theological colleges tended to overlook was the fact that what was already familiar to us was like a sudden blast of cold air to those who had no inkling of what had been going on in theological faculties in the previous few decades. Theology was normally published in hardbacks and in theological jargon that prevented the laymen from having ready access to them. In Honest to God some of this was put in a nutshell and published as a paperback. Some of Robinson's critics even complained that, by publishing it as a simple paperback, Robinson was making available to untheologically trained minds the weighty matters of theology they were not yet ready to understand.

So the book gave rise to widespread debate, and within six months the publisher, David Edwards of the SCM press, had published a second book The Honest to God Debate. This put together a selection of the thousand letters to Robinson, many extracts from hundreds of reviews along with articles by David Edwards, David Jenkins, John Macquarrie and Alasdair MacIntyre. The latter, an Oxford philosopher, concluded that Robinson had become an atheist like himself and believed Robinsons's desire to restate the faith in modern terms was 'a desperate attempt that cannot succeed'. He thought Robinson's 


\section{Lloyd Geering}

book simply reflected the changing face of religion in UK. His concluding words were, 'The creed of the English is that there is no God and that it is wise to pray to him from time to time'.

Yes, the book did reflect the changing face of religion, not only in UK but in the whole of the Christian world. One of the reasons it became such a best-seller is that it appeared just at the right time. When we now turn to look at Honest to God in its historical context we can see its importance as a marker in an ongoing process. In this respect it was the first of several related events that characterized the decade of the 60's.

This was the year in which Martin Luther King made his epochchanging address - 'I have a dream'. In 1966 the front cover of Times Magazine drew the attention of the world to the 'Death of God' theologians Thomas Altizer, William Hamilton and Paul van Buren. In 1966 the Jewish 'Death of God' rabbi, Richard Rubenstein wrote his After Auschwitz. Also in 1966 Joseph Fletcher published his Situation Ethics. This caused a stir reminiscent of Honest to God, and was followed similarly, but in 1968, by a volume documenting the response The Situation Ethics Debate.

In the decade of the turbulent 60's was 1966, the year in which we in New Zealand had our own widespread theological debate on the Resurrection of Jesus, culminating in the notorious 'heresy trial' of 1967.

So the ' 60 's proved to be a critical turning point for Western Christianity. As one churchman prophetically remarked, 'Things will never be the same again'. The decline in church attendance began rapidly to accelerate. It was as if Honest to God had blown the roof off the church. But though some put the blame on Robinson, and others like him, Honest to God was not the cause but only a significant marker in a transition which had started much earlier. Let us now turn to the broader picture of the changing face of religion.

We must go as far back as 1800 or, more specifically, 1799. (See my 1991 booklet, Religious Trailblazers, chapter 1.) 1799 was the year in which a rising theological star published a book which caused a stir in Germany not unlike that of Honest to God. It was called On Religion: Speeches to its Cultured Despisers. The latter term referred to the leading lights of the Enlightenment, thinkers such as David Hume, who were subjecting all religious claims to rigorous rational criticism and who were rejecting all appeal to divine revelation.

Written by Friedrich Schleiermacher, this book in its day was much more radical and challenging than Honest to God, and yet, instead of being 
condemned by critics from within the church. Schleiermacher was hailed as the one who salvaged Christianity from its rationalistic, atheistic critics of the Enlightenment. He was a hospital chaplain at the time he burst into print (anonymously at first) but, before long he was appointed to a Chair of Theology, first at Halle and soon after to one in the newly established University of Berlin, a chair he held until his death.

He was a very popular teacher and preacher who was so highly admired that nearly the whole of Berlin turned out to honour him at his funeral, when he died at the age of 66. His thinking dominated Protestant thought throughout the 19 th century, including my own theological teacher John Dickie. Dickie spoke of him as the most creative Christian thinker since the Reformation. Not surprisingly Schleiermacher became known as 'The Father of Protestant Liberalism'.

The widespread approval enjoyed by Schleiermacher while he lived tends to disguise the radical change in religious thought that he pioneered. Indeed, he did not himself appreciate or understand just what he was doing and certainly did not foresee all that his new method would lead to. He was much more of a revolutionary than he intended to be. It was left to others, such as John Dickie, to point to what they referred to as his faults and weaknesses. But Dickie was not nearly as critical as Karl Barth and even warned us against Barth and his revival of what was called Neo-orthodoxy. Karl Barth complained, and perhaps justifiably so, that Schleiermacher's new theological method heralded the end of Christian doctrine. He wrote, 'The question as to how Schleiermacher did not realise that he was destroying Reformation theology is a mystery which cannot be solved'.

Even Schleiermacher retreated somewhat from some of the more surprising statements in his first book when he came to compile his magnum opus - The Christian Faith. It is in his first two books, On Religion and a little known work Christmas Eve, that Schleiermacher, perhaps unintentionally, led theology in a new direction. Only very slowly did that new direction begin to show itself. It was not at all apparent while the momentum of church life carried on as it had in the past. It was still not apparent when I was a theological student in the thirties and forties. That is why the events of the sixties, including Honest to God was felt to be such shock - a virtual theological earthquake - for the very foundations of theology were being shaken.

Most of the people in the churches were completely ignorant of how western religious thought underwent a revolution at the beginning of the nineteenth century as a result of two seminal thinkers in Berlin - Hegel the 


\section{Lloyd Geering}

philosopher and Schleiermacher the theologian. Though very different from each other, they opened up the way for three further pioneer thinkers - Strauss, Feuerbach and Marx. Marx became a communist and militant atheist. Feuerbach came to understand religion as a human phenomenon, even though most important and one on which our very humanity came to depend. Strauss became the pioneer of modern New Testament study and this led to Bultmann and then to Robinson. Tillich became the 20th century equivalent to Schleiermacher in the 19th century and so to Robinson. In the meantime Karl Barth re-established orthodoxy as Neo-orthodoxy by returning to what obtained before Schleiermacher.

But what if one were unaware of those seminal first 50 years of the 19th century? My theological education as late as the early 40's left me in complete ignorance of them, apart from Schleiermacher. And even John Dickie emphasized the faults of Schleiermacher even more than his strengths. If even theological students were left in such ignorance, it means that in the early 60's most people in the pews knew absolutely nothing of the 19th century and what it had led to, until Honest to God suddenly came as a bomb shell. For most church people there seemed now to be only two alternatives - traditional Christianity and unbelief (atheism). Robinson appeared to them to be in a no-man's land and moving on the slippery slope towards atheism.

Let me now sketch three ways in which Schleiermacher triggered off the theological changes that led to the bombshell dropped by Robinson. These three features also describe the situation which became more widespread after Robinson and which obtains today.

First, Schleiermacher shifted the base on which to engage in the theological enterprise. Traditional theology started from God and the truths which God was believed to have revealed. It was theocentric. (So also was Barth's neoorthodoxy.) Schleiermacher's new theology started from humankind - from what we experience of the divine. It was anthropocentric. It was basically a shift from the study of divinely revealed truths (Dogmatics) to the study of personal religious experience. It was a shift from the objective to the subjective. (We have a good example of this in Bishop Jack Spong.)

The reason why such a radical shift did not seem to make much difference to begin with is that Schleiermacher and his appreciative supporters were so immersed in Christian orthodoxy that it permeated their minds and thinking as well as their hearts. Yet it was already leading Schleiermacher to make statements such as the following from On Religion, which even today may surprise. 
Religion answers a deep need in man. It is neither a metaphysic, nor a morality, but above all feeling .... Dogmas are not, properly speaking, part of religion: it is rather that they are derived from religion.

Then he said,

Belief in God is not necessarily a part of religion; one can conceive of a religion without God, and it would be pure contemplation of the universe.

It did not take long for Feuerbach to realise the consequences of what Schleiermacher had done. He studied for a short time under Schleiermacher but lost interest in preparing for the ministry and turned to philosophy and particularly to Hegel. But, by adopting Schleiermacher's anthropocentric basis for philosophy, he turned Hegel upside down; yet he never acknowledged his debt to Schleiermacher or seemed to be aware of it. He had probably read Schleiermacher's first book though he never says so. There he would have read:

Belief in personal immortality is not necessarily a part of religion .... The desire for personal immortality seems rather to show a lack of religion, since religion assumes a desire to lose oneself in the infinite, rather than to preserve one's own finite self.

It is interesting to find that Feuerbach's first publication, and at the age of 24, was Thoughts on Death and Immortality. Perhaps even this was due to the influence of Schleiermacher. But his seminal work was The Essence of Christianity. Here he took Schleiermacher's new anthropocentric base for theology to its logical conclusion. He asserted that theology (the study of God), when properly understood for what it really is, is anthropology (the study of humanity). Theology is the study of the human condition, of our highest human values, of our hopes and our aspirations. As Feuerbach saw it, the supernatural world acclaimed by Christian orthodoxy was largely the projection of humanity's inner world of ideas and values on to a cosmic backdrop.

That is why Schleiermacher, perhaps unintentionally, opened the way to the study of religion as a human phenomenon. There is a direct route from him also to Rudolph Otto and his seminal book The Idea of the Holy. Schleiermacher opened the way for the rise of the disciplines of The Psychology of Religion and 


\section{Lloyd Geering}

the Sociology of Religion. It also led to Don Cupitt and the Sea of Faith Network.

Second, Schleiermacher's switch from a divine starting-point to a human one took theology out of the hands of the authoritative experts - priests and theologians - and democratized it. Theology became a 'do-it-yourself' exercise in which everybody could participate, drawing upon their own inner experience. This is best illustrated by a little known book written by Schleiermacher himself, entitled Christmas Eve; A Dialogue on the Incarnation (1806).

In this he describes a homely fireside scene at which a gathering of friends (five women and four men) discuss what the celebration of Christmas means to each of them. They were no experts but ordinary people expressing how they thought about their own religious experience. Moreover, at a time when theology and even group discussion was still regarded as a male preserve, we find it is the women who initiate the discussion.

The women interpret the Nativity scene in the light of their feelings and experience as mothers. One claims, for example, that she regards Mary as a representation of every mother, who sees her own child as an eternal divine child in whom she looks for the first stirrings of the higher spirit. When the men subsequently take over the conversation, it moves to a more philosophical and, at times, impersonal level. Leonard, for example, is even said by his friends to be the 'thinking, reflective, dialectical, over-intellectual man'. He is aware that historical study of the Bible is already introducing uncertainty as to how much is really known about the historical Jesus. He doubts whether the organized church is at all in accordance with what was the intention of Jesus.

Ernst counters this scepticism by seeing Christmas as a universal festival of joy. Its continuing significance rests on what Christians have found to be vital in their own Christian experience and does not depend on whether the biblical story of the birth and life of Jesus is historically true.

In contrast to both, Edward the host is more speculative and mystical. He notes that in the Fourth Gospel there is no mention at all of the birth of Jesus at Bethlehem. Rather it affirms that the Word was made flesh - that Word that was with God and was God. The significance of Christmas for Edward is that,

what we celebrate is nothing other than ourselves as whole beings, viewed and known from the perspective of the divine.... What else is humankind than the very spirit of earth, or life's coming to know itself in its eternal being and in its ever changing process of becoming? 
(In 1806, and before the idea of evolution had spread, that was surely a most radical thought!).

Joseph, who arrived later in the evening, is a simple, naive and pious Christian who is rather shocked to find the men arguing almost heatedly on such an occasion. He reacts strongly to the coldly rationalist approach of Leonard and tries to restore some cheerful harmony to the evening, leading the party to end with some singing. It was no doubt quite deliberate on Schleiermacher's part to associate harmonious fellowship with the women, and intellectual discord with the men, just as the little story ended, not with statements of belief, but with the feelings engendered in a fellowship celebrating their common bonds.

Schleiermacher's little book of 1803 is a fascinating parable of what the theological scene was to become. It uncannily sketches the theological scene in the post-Christian world generally and of the Sea of Faith Network in particular. Today there are no more leading theologians to whom we gratefully turn for the authoritative answers to our questions about the meaning of life. Paul Tillich was perhaps the last creative theologian. There have been a few voices after Tillich, such as John Cobb, John Macquarrie, Gordon Kaufman, and Don Cupitt. In this 21 st century academic theology of the traditional style still continues but it is no longer at the leading edge of thought, as it was once, when it claimed to be the Queen of the Sciences. Theology is being marginalized into non-existence. Karl Barth was right in declaring that Schleiermacher's new theological method heralded the end of Christian doctrine.

The third way in which Schleiermacher's switch from a divine startingpoint to a human one led to the modern situation is that it opened the way for dispensing with the word 'God'. Curiously even Schleiermacher himself saw this when he said:

Belief in God is not necessarily a part of religion; one can conceive of a religion without God, and it would be pure contemplation of the universe.

But to most people then and, for a considerable time thereafter, the idea of 'God' was so axiomatic that it seemed to be indispensible. Even Don Cupitt, as late as 1980, said in Taking Leave of God, 'God is a myth we have to have'. Yet, only four years later John Macquarrie said in his Gifford Lectures, In Search of Deity, 
There was a time in Western society when 'God' was an essential part of the everyday vocabulary. But in the West and among educated people throughout the world, this kind of God-talk has virtually ceased. People once knew, or thought they knew, what they meant when they spoke of God, and they spoke of him often. Now in the course of the day's business we may not mention him at all. The name of God seems to have been retired from our everyday discourse.

In 1999 Don Cupitt made a study of our everyday discourse and he discovered that, as the word 'God' ceased to be in use, it was replaced by the word 'life'. Life has become theologized. He found more than 150 life idioms being commonly used today, many of them quite new such as 'Get a life!' He concluded that now that theology has been democratized (thanks to Schleiermacher) it is no longer the academic theologians but ordinary people, speaking out of the experience of living, who have been at the leading edge of 'theology'. He called this The New Religion of Life in Everyday Speech (1999).

\section{Summary}

The theistic image of God had to go. It was too small, too human, too personal, and too objective. 'God' remains as a symbolic term referring to all that transcends us, providing unity to the universe we live in.

Honest to God was a significant marker in the process by which Western culture moved from its traditional Christian base to its current non-theistic and post-Christian stance. It started with Schleiermacher but only since the 60's of the twentieth century did it lead to the increasingly rapid decline of the churches. The nature of this transition is particularly visible in the 'Progressive Christian Churches' and the Sea of Faith Network. Just as the Enlightenment gave us the freedom to think for ourselves, so, in the realm of theology we in the West are mostly becoming 'do-it-yourselfers' today.

\section{References}

Bonhoeffer, D. 2010. Dietrich Bonhoeffer Works. Volume 8: Letters and Papers from Prison. Minneapolis: Fortress Press. 
Bultmann, R. [1941] 1984. The New Testament and Mythology and Other Basic Writings. Augsburg: Fortress Publishers.

Bultmann, R. (and Five Critics) [1953] 2000. Kerygma and Myth. Ogden, S.M. (trans. \& ed.). London: SPCK, HarperCollins.

Church Times. Archive available at: https://www.churchtimes.co.uk/archive

Cox, H. 1968. The Situation Ethics Debate. Louisville \& London: Westminster Press.

Cupitt, D. 1999. The New Religion of Life in Everyday Speech. Available at: https://archive.org/stream/theideaoftheholy00ottouoft/theideaoftheholy0 0ottouoft_djvu.txt

Edwards, D. [1963] 2012. The Honest to God Debate. London: SCM Press. Feuerbach, L. 1980. Thoughts on Death and Immortality. Massey, J.A. (trans.). Berkeley \& Los Angeles; \& London: University of California Press. Feuerbach, L. 1881. The Essence of Christianity. $2^{\text {nd }}$ Edition. Evans, M. (trans.). London: Trübner \& Company. Available at: https://books.google.co.za/books?id=ki4RAAAAYAAJ\&printsec=frontc over\&source $=\mathrm{gbs} \_g e \_s u m m a r y \_r \& c a d=0 \# \mathrm{v}=$ onepage $\& \mathrm{q} \& \mathrm{f}=\mathrm{false}$

Fletcher, J. 1966. Situation Ethics: The New Morality. Louisville \& London: Westminster \& John Knox Press.

Geering, L. 1992. Religious Trailblazers. Wellington, NZ: St Andrew's Trust for the Study of Religion and Society, and Sea of Faith Network (UK).

Geering, L. 2013. Theology Before and After Bishop Robinson's Honest to God. Available at: http://www.sof.org.nz/2013geeringkeynote.pdf

King, M.L. Jnr. 1963. 'I have a Dream' - Speech. Available at: https://www.archives.gov/files/press/exhibits/dream-speech.pdf

Lawrence, D.H. [1928] 1960. Lady Chatterley's Lover. London: Penguin Books.

Otto, R. 1923. The Idea of the Holy: An Inquiry into the Non-Rational Factor in the Idea of the Divine and its Relation to the Rational. Harvey, J. (trans.). Oxford: OUP. Available at:

https://archive.org/stream/theideaoftheholy00ottouoft/theideaoftheholy00ot touoft_djvu.txt

Robinson, J.A.T. 1963. Honest to God. London: SCM Press.

Rothman, L. 2016. Is God Dead? Available at: http://time.com/isgoddead/ Rubenstein, R. [1966] 1992. After Auschwitz: History, Theology, and Contemporary Judaism. $2^{\text {nd }}$ Edition. Baltimore: The Johns Hopkins Press. 
Schleiermacher, F. [1799] 1893. On Religion: Speeches to its Cultured Despisers. Oman, J. (trans. and intro.). London: Kegan Paul, Trench, Trubner \& Co. Available at:

https://archive.org/stream/onreligionspeech00schluoft/onreligionspeech0 0schluoft djvu.txt

Schleiermacher, F. [1806] 2010. Christmas Eve Celebration: A Dialogue. Tice, T.N. (trans). Oregon: Cascade Books. Available at:

https://archive.org/details/christmasevedial00schl

Tillich, P. 1952. The Courage to Be. New Have \& London: Yale University Press. Available at:

http://www.pol-

ts.com/Research_files/Source\%20Material/Tillich/courageofbe011129m bp.pdf

Tillich, P. 1955. The Shaking of the Foundations. New York: Charles Scribner's. Out of Print. This online version for Religion Online was prepared by John Bushell. http://media.sabda.org/alkitab-2/ReligionOnline.org\%20Books/Tillich,\%20Paul\%20\%20The\%20Shaking\%20of\%20the\%20Foundations.pdf

Tillich, P. 1967. Systematic Theology. Volumes I - III. Chicago: University of Chicago Press.

Time Magazine 1966. Theology: The God is Dead Movement - Thomas Altizer, William Hamilton and Paul van Buren. Available at: http://content.time.com/time/subscriber/article/0,33009,941410,00.html

Lloyd Geering Emeritus: Religious Studies Victoria University lloydgeering0@gmail.com 